УДК $821^{\prime} 04.09$

Коломісць Н. $\boldsymbol{\Theta . , ~}$ кандидат філологічних наук, доцент кафедри української та світової літератур Криворізький державний педагогічний університет

\title{
ПОЕЗІЯ ВАГАНТІВ ЯК ВИРАЖЕННЯ СУБКУЛЬТУРИ СЕРЕДНЬОВІЧНОГО СТУДЕНТСТВА
}

У статті поезію вагантів розглянуто як продукт субкультури мандрівних студентів зрілого Середньовіччя. Значну увагу приділено осмисленню світогляду, життєвих настанов, етичних та естетичних ідеалів цьього суспільного прошарку та особливостям їх вираження у творах. Вказано на мандрівний спосіб життя вагантів; відзначено, щуо їх поезія була переважно анонімною; окреслено домінанти творчості Прімаса Орлеанського, Ахипї̈а Кельнського, Вальтера Шатільонського.

Ключові слова: Середньовіччя, поезія, ваганти, голіарди.

В статье поэзия вагантов рассматривается как продукт субкультуры бродячих студентов зрелого Средневековья. Значительное внимание уделено осмыслению мировоззрения, жизненных установок, этических и эстетических идеалов этого 
общественного слоя и особенностям их выражения в произведениях. Указано на странствующий образ жсини вагантов; отмечено, что их поэзия была преимущественно анонимной; очерчены доминанты творчества Примаса Орлеанского, Ахипиита Кельнского, Вальтера Шатильонського.

Ключевые слова: Средневековье, поэзия, ваганты, голиарды.

In the article the poetry of vagants considered as a product of the subculture of wandering students of the Mature Middle Ages. Considerable attention is paid to understanding of the worldview, life attitudes, ethical and aesthetic ideals of this social class and the peculiarities of their expression in works. It is pointed out on the peripatetic lifestyle of vagants; it is noted that their poetry was mostly anonymous; it is indicatedthe dominants in the creativity of Primas of Orleans, Archpoetof Cologne, Walter Chatilion.

Key words: Medieval, poetry, vagants, galardi.

На сучасному етапі в зарубіжному та вітчизняному літературознавстві простежується тенденція грунтовного вивчення літературного процесу пізнього Середньовіччя, зокрема лірики вагантів. Значний внесок у розроблення цієї наукової проблеми зробили О. А. Галич [Галич 2003:228], О. В. Сидоренко [Сидоренко 2006:20], М. С. Шаповалова [Шаповалова 1993:312], які досліджували жанрові особливості творів високого Середньовіччя. M. В. Кордон [Кордон 2003:508], А. Д. Михайлов [Михайлов 2006:349], А. В. Скрипник [Скрипник 2005:20] та ін. окреслили соціокультурну ситуацію доби.

Розквіт поезії вагантів, мандрівних поетів, що писали латиною, припадає на XIII століття. У цей час помітно зросла роль міста як територіальної та адміністративної одиниці в різних сферах середньовічного суспільного життя. «Імпульси, які йшли від ичього соціального організму, щзо об’єднав у собі форми економічного, політичного та духовного жстття, визначили перспективи розвитку суспільства в цілому» [ИСВ 2003:21]. Різними соціальними прошарками городян (цехових ремісників, нотаріусів, слуг, купців та ін.) сформовано систему нових суспільних стосунків (іноді аж до руйнування влади сеньйора та створення самоврядування). Ці зміни сприяли трансформації гносеологічної сфери та картини світу середньовічної людини. Мешканці міст у порівнянні із селянством відрізнялися відносними інформованістю, широтою світогляду та демократичністю поглядів. Моральні цінності, що домінували в середньовічному місті орієнтували людину на ідеали рівності та справедливості. 
Вони виражали інтереси більшості соціальних груп, визначали тип поведінки, необхідний конкретно-історичній ситуації. Ідеалу сеньйоро-васальної залежності, заснованому на експлуатації, віднині протистояла система цінностей, в основі якої стояла власна праця як запорука гідного життя. Городянами засуджувалося неробство, громадянська пасивність, безініціативність, непорядність. Неабиякої ваги набували такі моральні чинники, як: повага до праці, невичерпний оптимізм, життєва мудрість, хазяйновитість, дбайливість, самостійність тощо. Політичне визнання бюргерства ствердило думку про те, що права особистості не визначаються виключно іiі спадковою приналежністю до знатного роду. Розквіт літератури обумовило також зростання загального рівня освіченості, швидкі темпи розповсюдження та вдосконалення книгодрукування.

Зародження поезії вагантів тісно пов'язане з розвитком освіти та шкільної справи. На початку XII століття в Західній Європі виникали приватні школи прообрази перших європейських університетів. Вони були відносно незалежні від церковних організацій і тому вільніші у своїх діях. Найстаріші 3 них Паризький і Олонський університет. У XIII столітті утворено Оксфордський, Кембріджський, Тулузький, Саламанський і цілий ряд інших вищих навчальних закладів.

Незважаючи на те, що жодна епоха не виділяла студентство як окремий суспільний прошарок, що його склад був досить строкатим: бідні й багаті, старанні й ледачі, молодь і люди зрілого віку, ще від початку свого існування воно утворило специфічну соціокультурну групу. Ї̈̈ колективній психології притаманне вільнодумство, своєрідний нігілізм, мобільність, активне творче начало тощо. Субкультуру середньовічного студентства частково репрезентовано в ліриці вагантів.

Поняття ваганти походить від латинського слова vagantes - «бродячі люди». Їхня друга назва голіарди (вигадана самими вагантами в насмішку) утворена «від імені біблійського велетня-язичника Голіафа, якого вбив цар Давид. Однак, все це є лише пізнішим переосмисленням імені голіардів, яке, вірогідно, походить від латинського слова gula - «глотка»; таким чином, слово 
«голіарди» первинно означало «крикуни» або «любителі пойсти й випити» [ИЗЛ 1987:121].

Хоча саме університети ставали осередками, які формували традиції вагантів, мандрівними поетами були не лише студенти або школярі. Відомі поодинокі приклади, коли вагантські твори писали священики, що мали постійне місце праці, а іноді навіть займали стале становище при дворах знаті. Серед вагантів зустрічалися «й клірики без певних занять, щзо з’являлися то тут, то там, представники низового духівництва, не обтяжені щзедротами фортуни <..> Піднімаючи вагантів над масою «профанів», латинська мова залучала їх до духовної еліти середніх віків, разом із тим на сходах суспільної ієрархї того часу вони займали досить скромне місие. Знатні вельможі поглядали на них зверхньо» [Пуришев 1985:23].

Творчості голіардів притаманні внутрішньо неузгоджені установки: завищені амбіції та нереалізовані надії; прагнення незалежності, провокативна поведінка, забіякуватість та фактична приниженість; хвалькуватість, вип’ячування ученості, власної хитрості та жалість до своєї долі, відчуття пригніченості й безпорадності. Така психологічна роздвоєність вагантів відбивала їх становище в соціальному просторі. Із одного боку, порушуючи злободенні питання, висміюючи клір, вони виступали провісниками нових реформаційних поглядів; а з іншого, вдаючи злиденних невдах, перетворювалися на блазнів, ходили від двору до двору, співали, читали вірші й цим підробляли.

Мандрівний спосіб життя цих людей обумовлений не лише вільним, бунтарським світоглядом та опозиційними настроями, а й соціальними проблемами, передусім бідністю та невлаштованістю. Так, клірики відірвалися від свого соціального середовища; колишні студенти лишилися незапитаними суспільством, оскільки кількість кандидатур на місця служителів церкви перебільшувала вакансії; частина студентської громади не мала коштів на існування. «Якщуо спочатку офіиійне право жебракувати на вулииях міста надавалося лише членам цеху жебраків, то зрештою таке право надали $i$ нужденним иколярам. Вечорами вони збиралися під вікнами бюргерських 
домівок і співали. Успіху зазвичай досягали ті, в кого був не найкращий, $а$ найгучніший $і$ найпронизливіший голос. Городяни поспішали кинути у вікно їжу або монети, циим самим купуючи собі право на спокійний сон. 1522 р. міська рада Аугсбурга постановила, щзоб громадяни, які не бажають слухати волання під вікнами, щзомісяия вносили пожертви для студентів спеціальному уповноваженому. За изе на їхній будинок буде прикріплено жетон, побачивщи який, прохачі підуть далі. Проте, на жаль, цүих пожертв було недостатньо. Шукачі знань нерідко гинули на вулищі від голоду та злиднів» [Бажал 2006:2].

У цілому ряді творів звучить нарікання на бідність, нестатки, які мали розчулити слухачів i спонукати їх до щедрої матеріальної винагороди. Прикладом можуть бути рядки з поезії «Бідний студент»:

1. Стану я духовного.

Злидень поміж вами,

Для страждань народжений

Плентаюсь світами.

2. Я Я до всіх премудростей

Прагнув причаститись,

Тільки злидні капосні

Не дали довчитись.

3. Одяг подірявлений

На мені, недужім,

I в морозну днину я

Аж тремчу від стужі [ЛЗС 2003:386].

На крайню межу бідності ліричного суб’єкта вказують епітети «злидні капосні», «одяг подірявлений». Відчуття соціальної безперспективності передає повтор слова «злидень». У творі вжито згрубілу лексику «плентаюсь світами», яка створює ефект драматичного нагнітання.

Освіченість вагантства доби класичного Середньовіччя не спричинила втрату потягу до веселого, безтурботного життя. Вони називали себе слугами Венери й Вакха, а в піснях оспівували гру, вино та кохання. «У них існувала сила- 
силенна різноманітних способів пити вино й пиво. Німецькі студенти розробили цุілий статут для п'яницьь із дивними обрядами та церемоніями. Захмелівши, ярижники розповідали сороміцькі анекдоти, співали веселих пісень $і$ з'ясовували стосунки між собою. Чимало молодиків полягло в бійках і на дуелях, щце більше заробили синщі, переламані кістки та відбиті нирки. Та гнів свій <..> студенти зганяли не лише один на одному, а й на місиевих жителях. Сутички між городянами та школярами - явище так само звичне в ті часи, як шлюб без кохання〉 [Бажал 2006:3].

Ваганти нехтували всім, або майже всім, що вимагало від особи обтяжливої витримки й послідовності. Вони шукали ефектів потрясіння, пориву та контрасту. Їхня поезія уособлювала буяння молодості, бунтарського юного духу:

До богів подібні ми!

Як боги, кохаймося!

До забав жадібними

Бути не вагаймося!

Між дівочі хороводи

Юнаки, покваптеся,

Щоб не втратити нагоди,

Як нагода трапиться!

Приспів: Кинь книжки, бо пролетить

Час, немов на крилах,

Хай же душу веселить

Молодість грайлива! [ЛЗС 2003:389].

В осмисленні любові ваганти далекі від ідей куртуазії. Художній світ їх поезій, написаних на тему кохання, відкриває невичерпні джерела оптимізму ліричного суб’єкта, вводить у сферу інтимних почувань. Прямодушність у змалюванні найпотаємнішого, відвертість у відтворенні статевого інстинкту художньо трансформують тілесний бік кохання на пристрасне відтворення земного раю. Наприклад, приспів «Весняної пісні» містить такі рядки: 
Гай, гай! На душі розмай!

Прагну розкочів дівочих,

Що дарують рай!

Я згораю від кохання -

Світе, прощавай! [ЛЗС 2003:388].

Мандрівні поети мали філософський погляд на світ, насміхалися над різноманітними повсякденними негараздами, іронізували над догмами та канонами, а релігійні образи й мотиви змінювали та перероблювали на свій штиб. Вони були авторами інтелектуально гострих, а часом і парадоксальних поезій, у яких поєднувалося високе побожне та низьке сміхотворне, благочестивий текст i нечестивий контекст тощо. Їхні твори вирізнялися критичним ставленням до духовенства високих рангів. Прикладом може слугувати «Критика Риму» Вальтера Шатільйонського.

Поезія вагантів була головним чином анонімна. Однак збереглося кілька імен кліриків, які обіймали певні посади. Найвідоміше 3 них - Тугон на прізвисько Прімас (тобто Старійшина) Орлеанський. Його вірші здебільшого автобіографічні. Вони спрямовані проти іменитих ворогів, сповнені відвертих зізнань щодо інтимної сторони життя. Коханка в них постає не умовною красунею, а прозаїчною міською блудницею.

Інший поет відомий тільки по прізвиську - Ахипіїт Кельнський. Відомо, що він перебував при дворі імператора Фрідріха Барбаросси. У творах окреслював свої промахи, осміював життєві невдачі, зрідка показував власні досягнення. Його поезія «Сповідь» стала однією з найпопулярніших вагантських поезій в Європі.

Вальтер Шатільонський був майже однолітком Архипіїта Кельнського, працював при дворі Генріха II Плантагенета, короля Англії й половини Франції. Він $є$ автором епічної поеми в десяти книгах «Александріада», присвяченої висвітленню героїчних діянь Олександра Македонського. Величезний успіх мали його вагантські вірші, в яких звучав осуд світу, де правлять гроші. 
Отже, поезія вагантів була переважно анонімною. Вона частково репрезентує субкультуру середньовічного студентства, передає світогляд, життєві настанови, естетичні ідеали цього суспільного прошарку. Із творів мандрівних поетів можна виокремити складові колективної психології цієї групи людей (вільнодумство, своєрідний нігілізм, мобільність, активне творче начало тощо) та утворити поведінкову модель (відхід від практики обмеження, жага чуттєвих насолод, безжурне ставлення до життя, відмова від аскези тощо). Виконуючи свої твори, мандрівні поети вдавали злиденних невдах, перетворювалися на блазнів, ходили від двору до двору, співали, читали вірші й цим підробляли. Поезія вагантів порушувала наболілі соціальні питання, викривала недоліки, виступала своєрідним провісником нових реформаційних поглядів.

\section{БІБЛІОГРАФІЯ}

Бажал 2006 - Бажал А. Служитель Вакха, «мученик науки»: середньовічний студент? / Аліна Бажал [Електронний ресурс] // Дзеркало тижня. - 2006. - № 1 (580). - Режим доступу: http://www.osvita.org.ua/student/ studying/articles/5.html.

Галич 2003 - Галич О. А. Історія зарубіжної літератури. Античність. Середньовіччя / Галич О. А., Дмитренко В. І., Фоменко В. Г. - Луганськ : Янтар, 2003. $-228 \mathrm{c}$.

ИЗЛ 1987 - История зарубежной литературы. Средние века и Возрождение : учебник для филол. спец. вузов / Алексеев М. П., Жирмунский В. М., Мокульский С. С., Смирнов А. А. - [4-е изд.] - М. : Высшая школа, 1987. - 416 с.

ИСВ 2003 - История средних веков : учебник в 2 т. / под ред. С. П. Карпова. - [4-е изд.]. - М. : Высшая школа, 2003. - Т. 1. -640 с.

Кордон 2003 - Кордон М. В. Українська та зарубіжна культура : [курс лекцій] / М. В. Кордон. - К. : ЦУЛ, 2003. - 508 с.

ЛЗС 2003 - Література західноєвропейського середньовіччя / за ред. Н. О. Висоцької. - Вінниця : Нова книга, 2003. - 464 с. 
Михайлов 2006 - Михайлов А. Д. Французский рыцарский роман и вопросы типологии жанра в средневековой литературе / Андрей Дмитриевич Михайлов / [отв. ред. Н. И. Балашов]. - М. : URSS ; КомКнига, 2006. - 349 с.

Пуришев 1985 - Пуришев Б. И. Вальтер фон дер Фогельвейде и немецкий миннезанг / Борис Иванович Пуришев // Вальтер фон дер Фогельвейде. Стихотворения / Вальтер фон дер Фогельвейде / [изд. подгот. В. В. Левик и др.]. - М. : Наука, 1985. - С. 223-272. - (Серия «Литературные памятники»).

Сидоренко 2006 - Сидоренко О. В. Малі комічні форми в західноєвропейських літературах високого Середньовіччя і Ренесансу : автореф. дис. на здобуття наук. ступеня канд. філол. наук : спец. 10.01.05 «Порівняльне літературознавство» / О. В. Сидоренко. - К., 2006. - 20 с.

Скрипник 2005 - Скрипник А. В. Французький поетичний дискурс епохи Середньовіччя : автореф. дис. на здобуття наук. ступеня канд. філол. наук : спец. 10.02.05 «Романські мови» / А. В. Скрипник. - К., 2005. - 20 с.

Шаповалова 1993 - Шаповалова М. С. Історія зарубіжної літератури. Середні віки та Відродження / Шаповалова М. С., Рубанова Г. Л., Моторний В. А. [3-е вид. перероб і доп.]. - Львів : Світ, 1993. - 312 с. 